\title{
US Inflation and Commodity Prices: Analytical and Empirical Issues
}

Anastasios G. Malliaris

Loyola University Chicago, tmallia@luc.edu

Follow this and additional works at: https://ecommons.luc.edu/business_facpubs

Part of the Business Commons

\section{Author Manuscript}

This is a pre-publication author manuscript of the final, published article.

\section{Recommended Citation}

Malliaris, Anastasios G.. US Inflation and Commodity Prices: Analytical and Empirical Issues. Journal of Macroeconomics, 28, 1: 267-271, 2006. Retrieved from Loyola eCommons, School of Business: Faculty Publications and Other Works, http://dx.doi.org/10.1016/j.jmacro.2005.10.020

This Article is brought to you for free and open access by the Faculty Publications and Other Works by Department at Loyola eCommons. It has been accepted for inclusion in School of Business: Faculty Publications and Other Works by an authorized administrator of Loyola eCommons. For more information, please contact ecommons@luc.edu.

\section{(c) $($ () $\ominus$}

This work is licensed under a Creative Commons Attribution-Noncommercial-No Derivative Works 3.0 License. (C) Elsevier B. V. 2006 


\title{
U.S. Inflation and Commodity Prices: Analytical and Empirical Issues
}

\author{
A. G. Malliaris *, \\ *School of Business Administration, \\ Loyola University Chicago, \\ 1 East Pearson Street, Chicago, Illinois, 60611, U.S. \\ (Corresponding Author’s E-mail: tmallia@luc.edu)
}

\begin{abstract}
This paper reviews both theoretical and empirical issues regarding inflation and evaluates the contribution of Kyrtsou and Labys. Analytically it is very difficult to propose a general theory of inflation because as economies evolve over time both new causes of inflation emerge and the consequences of inflation become more complex. Kyrtsou and Labys perform several tests between the Primary Commodity Price component of the PPI and the CPI and construct a noisy chaotic multivariate model that describes the relationship between these two measures of inflation.
\end{abstract}

Keywords: Inflation, Commodity Prices, Chaos, Non-linear causality, dynamic non-linearity, Mackey-Glass model

JEL Classification: C22, C23, E31, E60

October 2005, Journal of Macroeconomics, forthcoming 


\section{Introduction}

Inflation is broadly defined as the process of continuously rising prices.

Since there are several ways to measure the rate of price increases therefore there are also different measures of inflation. Currently, the most commonly used monthly measure of inflation is the percentage change in the Consumer Price Index and the most common quarterly measure is the percentage change in the Gross Domestic Product Implicit Price Deflator.

Economic historians have documented various inflations both across countries and time periods. In general, however, inflation statistics prior to the $20^{\text {th }}$ century are limited with very few exceptions. Froot, Kim and Rogoff (1995) consider annual commodity price data from England and Holland over a span of seven centuries for a limited group of 8 commodities. Block, Dockery and Sapsford (2004) study commodity prices, and U.S. inflation during the twentieth century. Similarly, Anna Schwartz (1973) and Malliaris (2005) discuss U.S. inflation in its historical perspective and document price inflation and deflation as a feature of economies that use money as a means of exchange. Sargent (1982) describes how four major inflations ended. In recent times, several Latin American economies have experienced rapid inflations. Thus, economists consider inflation to be a research topic of major significance. 
Evidence of the importance of inflation as an area of inquiry is found both in the sizeable volume of literature and the establishment of price stability as a major goal of national macroeconomic policies. Actually, the literature is so large that no one has recently attempted to survey the field. Comprehensive surveys written earlier include Bronfenbrenner and Holzman (1963) and the two books by Parkin and Zis (1976a, 1976b).

In this paper we briefly review both analytical and empirical issues on inflation with special emphasis on the recent contribution of Kyrtsou and Labys (2005). A brief summary is found at the end of the paper.

\section{Analytical Approaches}

To understand the possible causes and potential consequences of inflation, it is methodologically suitable to distinguish between anticipated and unanticipated inflation. Anticipated inflation occurs when prices increase at a rate of growth that all economic agents expect and no one is caught by surprise. For example, if the money supply grows significantly faster than real output and economic agents know this development, such money growth will be associated with higher expected inflation, a higher level of wages, a higher level of nominal interest rates and a depreciation of the country’s exchange rate, among other economic developments. History 
teaches us that numerous countries during periods of war follow very easy monetary policies leading to anticipated inflation. A typical example is the period of the Vietnam War in the U.S. during the late 1960s and early 1970s with its easy monetary policy and inflation. In addition to wars, several Latin America countries have experienced rapid monetary growth caused by monetizing large public deficits leading to predictable inflation.

Economic analysis is not unambiguous about the consequences of anticipated inflation on real variables. Arguments have been developed to support all three logical consequences of anticipated inflation on real economic variables. First, we can claim that anticipated inflation does not affect any real variables, that is, monetary growth is neutral. Second, we can also develop a theory that supports the notion that fast monetary growth contributes to higher real output because of the celebrated Mundell-Tobin effect. This effect claims that higher anticipated inflation increases the opportunity cost of money balances and economic agents proceed to reallocate resources away from money and towards physical capital that increase output. Third, we can also argue that the decreasing value of money due to anticipated inflation may induce more consumption spending and lower savings leading to lower investment and a lower capital accumulation with an eventual decline in real output. Briefly put, even the simple case of 
anticipated inflation does not offer concrete predictions about the consequences of inflation.

Unexpected or unanticipated inflation is much more complex analytically. Causes of inflation may conveniently be distinguished between demand pull or cost push but this is a simplification because most fundamentals involve both aggregate supply and demand shifts. For example the recent dramatic increase in oil prices is due to both increased global demand, particularly from China's rapid economic growth but also due to supply shortages. Classical, Neo-Classical, Keynesian, NeoKeynesian, Real Business Cycle and other macroeconomic doctrines address potential causes of unanticipated inflation and trace its various consequences.

In general, unanticipated inflation most often is caused by unexpected shocks to aggregate supply and/or demand. Typical examples include, among others, an increase in aggregate demand because of demographics, an increase in aggregate consumption caused by increases in wealth, an increase in aggregate investment due to a major technological innovation or improved animal spirits, harvest failures due to weather conditions, increases in energy prices due to natural disasters and wars that destroy oil production and wage increases because of labor shortages. Since it is difficult to 
anticipate any such autonomous shocks and even more complicated to trace their consequences, monetary policies in advanced economies have been charged to monitor price developments and pursue price stability.

\section{Empirical Results}

To achieve the goal of price stability, central bankers monitor numerous indicators of inflation, including commodity prices. Furlong and Ingenito (1996) examine the empirical relationship between changes in commodity prices and inflation. Their results indicate that there is a link between inflation and commodity prices, but this link has changed considerably over time. Specifically, commodity prices were statistically robust leading indicators of inflation during the 1970s and early 1980s but they have been poor stand-alone indicators of inflation since the early 1980s. Awokuse and Yang (2003) also examine the usefulness of the behavior of commodity prices in formulating monetary policy and conclude that commodity prices signal the future direction of the economy. Mahdavi and Zhou (1997) distinguish between commodity prices and gold prices as leading indicators of inflation. Using an error-correction model they find evidence of cointegration between commodity prices and the consumer price index and also find that the evolution of the price of gold is not as important as general commodity prices. 


\section{The Contribution of Kyrtsou and Labys}

Kyrtsou and Labys (2005) perform several important statistical tests to uncover possible empirical relationships between commodity prices and inflation. Commodity prices are represented by the Primary Commodity Price component of the Producer Price Index -COMP, computed by the Bureau of Labor Statistics. Inflation is measured by the Consumer Price Index series -CPI, also calculated by the Bureau of Labor Statistics. The authors use monthly data beginning in January 1970 and ending in July 2002, for a total of 511 observations for each series.

Conceptually these two indexes are constructed to measure inflation for different goods and services. The CPI measures the average change over time in the prices of goods and services paid by consumers while the COMP measures average changes in prices received by domestic producers for their output of primary commodities. The earlier section on the analytics of inflation suggests that anticipated inflation with money neutrality will cause an increase in all prices and therefore in both the COMP and the CPI. Such increases need not occur simultaneously but rather may develop with certain speeds and certain lags. However, theoretically we cannot formulate a certain hypothesis about the relationship between the COMP and the CPI because inflation theories do not propose definite transmission mechanisms. 
In particular in the case of unanticipated inflation, our inability to formulate a clear hypothesis is even greater.

Kyrtsou and Labys (2005) proceed atheoretically to study these two series and do a remarkably comprehensive statistical task. Unlike other empirical studies in the same topic where authors use rather traditional statistical tools such as Granger causality and cointegration tests, errorcorrection models and VAR modeling, Kyrtsou and Labys apply a novel three step methodology. First they perform tests for linear cointegration between the COMP and CPI. Second, if such linear cointegration is found, they go further to test for non-linear Granger causality. Third, if non-linear Granger causality is found, they check for bi-directional non-linear causality to confirm evidence for non-linear feedback. In this case they apply the multivariate noisy Mackey-Glass process to check for chaotic interdependence. Thus their testing is both thorough and revealing because they discover dynamic non-linear feedback inter-dependencies.

The impressive findings of Kyrtsou and Labys that the complex dynamics between the COMP and the CPI can be approximated by a bivariate noisy Mackey-Glass process challenges monetary theorists to formulate appropriate inflation hypotheses that focus on both causality and feedback. 


\section{Summary}

This paper reviews rapidly both theoretical and empirical issues regarding inflation and evaluates the contribution of Kyrtsou and Labys. Analytically it is very difficult to propose a general theory of inflation because as economies evolve over time both new causes of inflation emerge and the consequences of inflation become more complex. Anticipated inflation is relatively easy to understand as agents observe the rapid increase in the money supply and correctly predict increases in prices. What is not certain is the impact of such price increases on real variables like employment and output. When inflation is the result of some autonomous shock, both the causes and consequences of unexpected inflation become interrelated with business fluctuations. In this case, economic theorizing takes place after the fact since one cannot always anticipate with high probability the unexpected. With limited guidance from the analytics of inflation, econometricians have performed numerous tests to identify leading indicators of inflation. Kyrtsou and Labys perform several tests between the COMP and the CPI and construct a noisy chaotic multivariate model that describes the relationship between these two measures of inflation. 


\section{References}

Awokuse, T. and J. Yang (2003), The Informational Role of Commodity Prices in Formulating Monetary Policy: A Reexamination, Economics Letters, 79, 219-224.

Bloch, H., M. Dockey and D. Sapsford (2004), Commodity Prices, Wages and U.S. Inflation in the Twentieth Century, Journal of Post Keynesian Economics, 26, 523-545.

Bronfenbrenner, M. and D. Holzman (1963), A Survey of Inflation, American Economic Review, 53, 593-661.

Froot, K., M. Kim and K. Rogoff (1995), The Law of One Price Over 700 Years, National Bureau of Economic Research Working Paper \#5132.

Furlong, F. and R. Ingenito (1996), Commodity Prices and Inflation, Federal Reserve Bank of San Francisco Economic Review, 27-47.

Kyrtsou, C. and W. Labys (2005), Evidence for Chaotic Dependence Between U.S. Inflation and Commodity Prices, Journal of Macroeconomics, this issue.

Mahdavi, S. and S. Zhou (1997), Gold and Commodity Prices as Leading Indicators of Inflation: Tests of Long-Run Relationship and Predictive Performance, Journal of Economics and Business, 49, 475-489.

Malliaris, A. (2005), Economic Uncertainty, Instabilities and Asset Bubbles. Hackensack, New Jersey: World Scientific Press.

Parkin, M. and G. Zis (1976a), Inflation in the World Economy. Manchester: Manchester University Press.

Parkin, M. and G. Zis (1976b), Inflation in Open Economies. Manchester: Manchester University Press.

Sargent, T. (1982), The Ends of Four Big Inflations, in R. Hall (editor), Inflation: Causes and Effects. Chicago: University of Chicago Press. 
Schwartz, A. (1973), Secular Price Change in Historical Perspective, Journal of Money, Credit and Banking, 5, 243-269. 